\title{
Role of Landscape Scale in the Distribution of Rodents in an Agroecosystem of Argentina
}

\author{
Jimena Fraschina ${ }^{1}$, Vanina A. León ${ }^{1} \&$ María Busch ${ }^{1}$ \\ ${ }^{1}$ Laboratorio de Ecología de Poblaciones, Departamento de Ecología, Genética y Evolución, Instituto IEGEBA \\ (CONICET-UBA), Facultad de Ciencias Exactas y Naturales, Universidad de Buenos Aires, Ciudad Autónoma de \\ Buenos Aires, Argentina \\ Correspondence: Vanina A. León, Laboratorio de Ecología de Poblaciones, Departamento de Ecología, Genética y \\ Evolución, Instituto IEGEBA (CONICET-UBA), Facultad de Ciencias Exactas y Naturales, Universidad de \\ Buenos Aires, Ciudad Autónoma de Buenos Aires, Argentina. E-mail: vleon@ege.fcen.uba.ar
}

\author{
Received: September 24, 2014 Accepted: October 27, 2014 Online Published: November 15, 2014 \\ doi:10.5539/jas.v6n12p22 URL: http://dx.doi.org/10.5539/jas.v6n12p22
}

\begin{abstract}
The goal of this study was to assess the effect of the different habitats on rodent diversity, and to estimate the effect of changes in land use on the rodent abundance through different possible scenarios. We sampled poultry farms, human houses, riparian habitats, railway embankments, woodlots, pasture, crop fields and their borders. The habitats with highest frequency of captures were poultry farms and crop field borders, mainly because of Mus musculus and Akodon azarae captures, respectively. All rodent species were found in at least six of the nine habitats sampled, but in some of them with low frequency. The different habitats differed in their contribution to the abundance of each species. Crop fields and pasture borders contributed more than $40 \%$ to the abundance of $A$. azarae, Oxymycterus rufus, Oligoryzomys flavescens and Calomys musculinus, while poultry farms had higher abundance of M. musculus. Woodlots and railway embankments showed a high contribution to $O$. flavescens abundance. The increase in the area covered by crop fields and human habitats led to an increase in the abundance of M. musculus and Calomys spp. and to a decrease in the relative abundance of other species. Considering the role of habitat diversity in rodent diversity, our results suggest that none of the species studied, except M. musculus, which is highly dependent on farms, depends on a single habitat and that their abundance is supported by a variety of less perturbed habitats. The current changes in land use would generate an increase in M. musculus abundance in detriment of wildlife species which are associated with undisturbed habitats.
\end{abstract}

Keywords: agroecosystem, distribution, landscape structure, rodents

\section{Introduction}

In temperate ecosystems, diversity is being increasingly affected by the expansion of urbanization and agriculture over natural systems, especially in developing countries (Tilman et al., 2001; Ramankutty et al., 2002). These changes may cause the disappearance or fragmentation of habitats, which in turn affect the composition, structure and function of communities and landscapes (Mc Garigal \& Mc Comb, 1995; Schweiger, Diffendorfer, Holt, Pierotti, \& Gaines, 2000).

In South America, the Río de la Plata grasslands have been transformed in crop fields at very high rates since the beginning of the 20th century. In the 1880 s, less than $10 \%$ of the area was occupied by crop fields, while in the 1930s this proportion increased to more than 25\% (Vervoorst, 1967; Soriano et al., 1991; Hall, Rebella, Ghersa, \& Culot, 1992; Viglizzo et al., 2001). This trend has also occurred in Argentina (Vega, Balde, Jobbagy, \& Paruelo, 2009). In Buenos Aires province, for example, the area covered by annual crops increased from $20 \%$ in 1988 to nearly $26 \%$ in 2002 (Vega et al., 2009). As a consequence of this expansion, the area covered by natural vegetation has decreased and is now present in small patches or corridors surrounding crop fields, along roads, in riparian habitats and along abandoned railway embankments. These types of habitats support spontaneous plant communities with a physiognomy similar to that of the original vegetation and composed of a variety of native and exotic species (Crespo, 1966; Mills, Ellis, McKee, Maiztegui, \& Childs, 1991; Bilenca \& Kravetz, 1995; Busch, Miño, Dadon, \& Hodara, 2001; Busch, Bilenca, Cittadino, \& Cueto, 2005). These habitats are less disturbed than agricultural fields, maintaining high plant cover throughout the year, and provide good habitats for small rodent species (Busch \& Kravetz, 1992; Ellis et al., 1997; Bilenca \& Kravetz, 1998). 
Along with the physiognomic changes of the landscape, the replacement of the grassland matrix by crop fields has also affected the landscape structure and function (Viglizzo et al., 2001; Ghersa, Ferraro, Omacini, Martinez-Ghersa, \& Perelman, 2002; Guershman, Paruelo, \& Burke, 2003; Donald, 2004), with spontaneous plant communities developed along longitudinal habitats functioning as corridors among habitat patches that are spatially separated by an unsuitable matrix (Forman \& Gordon, 1986). The presence of patches of natural habitats and corridors within the agricultural matrix may increase the abundance and diversity of various animal taxa (Hassall, Hawthorne, Maudsley, White, \& Cardwell, 1992; Salek, Kreisinger, Sedlacek, \& Albrecht, 2009), and favor the dispersion of various species (Aars \& Ims, 1999; Haddad et al., 2003).

Many studies have shown that rodents are very sensitive to changes caused by the expansion of agroecosystems (Grant, Birney, French, \& Swift, 1982; Bilenca \& Kravetz, 1995; Angelstam \& Petterson, 1997; Cole, Mc Comb, Newton, Leeming, \& Chambers, 1998; Masters, Brown, Clarke, Whittaker, \& Hollier, 1998). This may affect community composition because species respond differentially depending on their habitat affinities, food habits, range of movements and social interactions (Bowers \& Dooley, 1991; Robinson et al., 1992; Bolger et al., 1997; Millán de la Peña et al., 2003; Butet et al., 2006; Michel, F. Burel, \& A. Butet, 2006).

In the Pampean region, the agricultural expansion has caused changes in the relative abundances of native rodents, with an increase in those associated with more perturbed habitats in detriment of those typical of more stable habitats (Crespo, 1966; Kravetz, Percich, Zuleta, Calello, \& Weissenbacher, 1986). Along with the agricultural expansion, during the last decades, the size of agricultural plots has increased, and areas that were previously left as margins with spontaneous vegetation are now cultivated, decreasing the area occupied by corridors (Poggio, Chaneton, \& Ghersa, 2010). Therefore, the crop field matrix is increasing its dominance, along with an increase in woodlots, human houses and poultry farms or other intensive rural activities (Fraschina, 2011). In consequence, we expect that the change in the proportion of habitats will be reflected in the relative abundances of rodent species at a landscape scale, even if the species composition in each habitat type remains unchanged. The species distribution among habitats, independently of total abundance, may affect the performance of populations and their ability to persist in a system with an agricultural matrix and natural patches restricted to longitudinal corridors.

The rodent community in the Pampean region has been widely described (Busch \& Kravetz, 1992a, 1992b; Busch, Alvarez, Cittadino, \& Kravetz, 1997; Busch, Miño; Dadon, \& Hodara, 2000; Busch et al., 2001; Hodara, Busch, Kittlen, \& Kravetz, 2001; Hodara \& Busch, 2006; Busch \& Hodara, 2010; Fraschina, León, \& Busch, 2012; León, Fraschina, Guidobono, \& Busch, 2013), but mainly in crop fields, their borders, and poultry farms. Other habitats that support species with more specific requirements, such as railway embankments, woodlots and riparian habitats, have been poorly sampled. Taking into account that changes in land use mainly affect these types of habitats, which may be important for the maintenance of rodent diversity at a landscape scale, the goal of this paper was to assess the effect of the different habitats on rodent diversity at a landscape scale, and to estimate the effect of changes in land use on the abundance of the different species through different possible scenarios. Our hypothesis was that habitat heterogeneity allows the persistence of a higher rodent diversity, especially because some native species are restricted to natural habitats with low human intervention.

\section{Material and Methods}

\subsection{Study Area}

Field work was conducted in Exaltación de la Cruz Department (34 $\left.18^{\prime} \mathrm{S}, 59^{\circ} 14^{\prime} \mathrm{E}\right)$, Buenos Aires Province, Central Argentina. The study area is located in the Rolling sub-region of the Pampean Region, and is characterized by a temperate climate, with a mean annual temperature of $16{ }^{\circ} \mathrm{C}$ and an average annual precipitation of $1000 \mathrm{~mm}$. Maximal temperature occurs in January, with a mean temperature of $23.4^{\circ} \mathrm{C}$ and a maximum of $41.5^{\circ} \mathrm{C}$, while the coldest months are June - July, with a mean winter temperature of $9.8^{\circ} \mathrm{C}$ and a minimum of $-9.6^{\circ} \mathrm{C}$ (Hall et al., 1992). Although there are seasonal variations in precipitation, there is no dry period (Hall et al., 1992).

The original grasslands of the area have been highly modified by agriculture and livestock, and by the introduction of trees (Soriano et al., 1991). Nowadays, the study area is an agroecosystem that presents a matrix of crop fields that are frequently disturbed by agricultural activities, ploughing and herbicide application. The most frequent crops of the area include soybean, maize and wheat. Crop field size varies between 4 and 25 hectares, and crop fields are usually separated by thin corridors along wire fences where a spontaneous and particular flora is present (Soriano et al., 1991), with both native and exotic plant species. This spontaneous community is also developed along roads, railways and riparian habitats and is less disturbed by agricultural labors and livestock than fields (Busch \& Kravetz, 1992; Bilenca \& Kravetz, 1998). The area also has small 
patches of woodlots, houses and poultry farms. Most roads are unpaved. The main activity is rural work.

The habitats considered in the present study cover about $99 \%$ of the area, and include:

1 - Crop fields.

2 - Weedy edges (or borders) of crop fields.

3 - Pastures (fields covered with spontaneous vegetation that usually support livestock).

4 - Weedy edges (or borders) of pasture fields.

5 - Woodlots (small patches of about 0.5 to 2.5 ha with trees of about $5 \mathrm{~m}$ high and their juveniles).

6 - Riparian habitats (habitats along small streams that are dry at some moments of the year and are characterized by spontaneous herbaceous vegetation associated with wet conditions).

7 - Railway embankments (longitudinal habitats usually covered by spontaneous herbaceous vegetation and trees, because the train is no longer operative).

8 - Poultry farms (farms devoted to breeding chickens, which occupy about 1 ha, usually have three breeding sheds, and are surrounded by wire fences along which there is a weed community, similar to that of crop field borders). These farms frequently limit with crops or livestock fields.

9 - Human houses (urban houses located in a small village of about 500 inhabitants and houses dispersed within small fields, pastures and poultry farms).

Rodent communities in the study area are mainly composed of the sigmodontines Akodon azarae, Calomys laucha, Calomys musculinus, Oligoryzomys flavescens, and Oxymycterus rufus, the caviidae Cavia aperea and the introduced murines Rattus rattus, $R$. norvegicus and Mus musculus. These species show a differential habitat use, probably related to particular adaptations to perturbations and to interspecific interactions (Busch \& Kravetz, 1992). A. azarae, O. flavescens, O. rufus and C. aperea are more abundant in less disturbed habitats like roads and crop field borders, railways and riparian habitats. C. laucha is more frequent in crop fields and C. musculinus in crop field borders. Habitat use of both species of Calomys is restricted by the competitive dominance of $A$. azarae, which prefers less disturbed habitats with high plant cover (Busch et al., 2000; Busch et al., 2001). M. musculus and Rattus spp. are present in poultry farms and around human houses, but they are rare in rural and sylvan habitats (Crespo, 1966; Kravetz et al., 1986; Mills et al., 1991; Busch \& Kravetz, 1992a, 1992b). In rural habitats, native rodents show seasonal variations in abundance, with a minimum in spring, a peak in autumn-early winter and a decrease in late winter after frosts (Crespo, 1966).

\subsection{Habitat Description}

To describe the landscape of the study area and to define the different types of habitats, we traveled along major and minor roads, covering an approximate area of $1000 \mathrm{~km}^{2}$ recording the presence of different types of habitats. We then used Google Earth images to determine the proportions occupied by the different habitats defined.

\subsection{Rodent Sampling}

To cover the different stages of the rodent population (according to reproductive activity and density) and all the phenological stages of the crops, seasonal rodent samplings in crop fields, pastures, their borders, riparian habitats, railway embankments, woodlots, and human houses were conducted from June 2006 to March 2008. Samplings in poultry farms were conducted from December 2004 to May 2006. Because the composition of the rodent community and relative abundance in poultry farms do not show great changes according to the year (Gómez Villafañe \& Busch, 2007; Miño, Cavia, Gómez Villafañe, Bilenca, \& Busch, 2007), we considered valid to include this habitat in the study. Along the study period, we sampled rodents with Sherman live traps in a total of 350 sites. In riparian habitats, woodlots and railways embankments, we sampled sites with a line of 15 traps spaced at 10-meter intervals. In human houses, we distributed the 15 Sherman traps in the perimeter, garden and around other buildings. In each season, we sampled three sites per habitat. At each site of crop fields and pastures, we placed two lines of 15 traps spaced at 10-meter intervals: one in the border and the other in the field, 20 meters away from the border. In each season, we sampled three sites of each crop present. In all occasions, each site was sampled once. In 30 poultry farms, we placed 10 Sherman traps along the external walls of three breeding sheds, except in those that had only two. We also placed 10 traps along the perimeter of the farms. Some farms were sampled in more than one occasion, totaling 86 samplings.

Traps were baited with rolled oats mixed with peanut butter. Each trap was checked in the morning during three subsequent days at each trapping session. The location and habitat of capture, species, sex, external measures (body and tail length), body weight and external evidence of reproductive condition were recorded for each 
animal captured. Animals captured were given an individual mark with an ear tag and then released at the site of capture.

\subsection{Data Analysis}

Total rodent abundance and abundance of each species were estimated by a trapping success index (TS) $=$ number of different individuals captured / number of traps $\mathrm{x}$ number of nights in each habitat and period of the year (spring-summer and autumn-winter).

Species richness, diversity, evenness and total rodent abundance were estimated at each habitat. Diversity and Evenness were determined using the Shannon-Wiener (H) and Shannon Evenness (E) indexes, respectively (Magurran, 1988; Krebs, 1989).

The similarity in the composition of the rodent community among habitats was evaluated by the Czekanowski's quantitative index (Matteucci \& Colma, 1982; Pielou, 1984). In this analysis, we considered all captures along the study period.

We considered the species distribution among habitats at two scales: frequency of use of the habitat type (considering only presence/absence) and TS at each habitat type. In both cases, we conducted Generalized Linear Models (GLM) with binomial error structure and a logit-link function. If data showed over dispersion (dispersion factor larger than 1.5), we used GLM with a penalized quasi-binomial model (R Development Core Team 2013). Least Significant Difference (LSD) comparisons and Bonferroni correction were used if the effect of habitat was significant in the GLM analysis (Di Rienzo et al., 2014). We estimated the frequency of each species according to the number of sites with at least one individual captured in relation to the total number of sites sampled for each habitat along the study period and for each sampling. For each species, we only included those habitats where the species was captured at least once.

The relative representation of each habitat in the area was estimated from Google Earth images and maps of the study area.

We described habitat heterogeneity by means of the Shannon-Wiener $(\mathrm{H})$ index of diversity and Shannon Evenness (E) index (Ricklefs, 1987; Kotliar \& Wiens, 1990; Levin, 1992; Wiens et al., 1993) for the current area and scenarios 1 and 2 .

To assess the contribution of each habitat to rodent abundance at the lanscape scale, we multiplied the proportion of the area covered by the habitat by rodent abundance. We analyzed the effect of possible changes in land use on species composition at a landscape scale through four scenarios of possible change (Table 3 ). In all cases, we assumed an increase in the area occupied by poultry farms, crop fields and human houses and a decrease in the area occupied by woodlots, pastures, crop fields and pasture borders. We assumed no change in riparian habitats and railway embankments. In scenarios 1 and 2, we considered only changes in the proportion of the different habitats; in scenarios 3 and 4, we considered the same area proportions as in scenario 2 but with an increase in the size of crop field plots through the fusion of contiguous crop fields leading to the loss of internal borders. We assumed that rodents only use the crop field area located closer than $50 \mathrm{~m}$ to the border, so an increase in the size of the plots leads to a greater proportion of the crop field not used by rodents. The $50 \mathrm{~m}$ distance was chosen according to Hodara and Busch (2006). For these scenarios, we considered that increasing plot sizes were associated with declining rates of use by rodents ( 75 and $50 \%$ ).

\section{Results}

In all habitats except poultry farms, we captured a total of 635 individuals: $428 \mathrm{~A}$. azarae, $53 \mathrm{O}$. flavescens, $60 \mathrm{O}$. rufus, 51 C. laucha, 29 C. musculinus and 14 M. musculus, with a total capture effort of 8,370 trap nights. In poultry farms, we captured a total of 781 individuals, 678 M. musculus, 75 A. azarae, 6 O. flavescens, 7 O. rufus, and 5 C. laucha, with a total capture effort of 3,840 trap nights.

In riparian habitats and borders of crop fields and pastures, we captured all the species of the study area. In poultry farms, we captured five species, and it was the habitat with the highest total abundance, with a great dominance of M. musculus ( $85 \%$ of the captures). In human houses, we found the lowest richness, diversity and total abundance (Table 1). 
Table 1. Richness, diversity, evenness and total rodent abundance of all habitats sampled

\begin{tabular}{lllll}
\hline Types of habitats & S & H & E & Total TS \\
\hline Riparian habitats & 6 & 0.914 & 0.510 & 0.0568 \\
Crop field Borders & 6 & 0.894 & 0.499 & 0.091 \\
Pasture Borders & 6 & 1.114 & 0.622 & 0.0989 \\
Crop fields & 4 & 1.003 & 0.724 & 0.0141 \\
Poultry Farms & 5 & 0.599 & 0.372 & 0.0777 \\
Woodlots & 4 & 1.056 & 0.762 & 0.0196 \\
Pastures & 4 & 0.783 & 0.565 & 0.0414 \\
Human houses & 2 & 0.513 & 0.739 & 0.0084 \\
Railway Embankments & 4 & 1.037 & 0.748 & 0.0327 \\
\hline
\end{tabular}

Note. $\mathrm{S}=$ Richness, $\mathrm{H}=$ Diversity, $\mathrm{E}=$ Evenness, $\mathrm{TS}=$ total rodent abundance.

Poultry farms had low similarity to the other habitats, except to human houses, with a mean index of similarity of $14.91 \%$ (Czekanowski index, Table 2). The habitats with highest similarity were railway embankments and pasture borders $(94.74 \%)$ and crop field borders and riparian habitats $(94.37 \%)$. Habitats with low human intervention, as riparian habitats, pastures, railway embankments, pasture and crop field borders showed more than $77 \%$ similarity (Table 2 ).

Table 2. Czekanowski index among habitats considering all captures along the study period

\begin{tabular}{llllllllll}
\hline Habitat & $\mathrm{R}$ & $\mathrm{CB}$ & $\mathrm{PB}$ & $\mathrm{C}$ & $\mathrm{PF}$ & $\mathrm{W}$ & $\mathrm{P}$ & $\mathrm{H}$ & $\mathrm{RE}$ \\
\hline $\mathrm{R}$ & 1 & 94.379 & 83.101 & 60.056 & 18.176 & 66.785 & 89.565 & 23.987 & 77.464 \\
$\mathrm{CB}$ & & 1 & 86.016 & 57.084 & 14.907 & 69.964 & 91.111 & 21.171 & 83.085 \\
$\mathrm{~PB}$ & & & 1 & 57.956 & 17.16 & 75.67 & 81.722 & 23.424 & 94.744 \\
$\mathrm{C}$ & & & & 1 & 14.536 & 53.566 & 62.4 & 22.682 & 54.471 \\
PF & & & & & 1 & 11.53 & 13.456 & 89.928 & 14.632 \\
W & & & & & & 1 & 61.35 & 20.896 & 77.243 \\
P & & & & & & & 1 & 20.896 & 78.994 \\
H & & & & & & & & 1 & 20.896 \\
RE & & & & & & & & & 1
\end{tabular}

Note. $\mathrm{R}=$ riparian habitat, $\mathrm{CB}=$ crop field border, $\mathrm{PB}=$ pasture border, $\mathrm{C}=$ crop fields, $\mathrm{PF}=$ poultry farms, $\mathrm{W}=$ woodlots, $\mathrm{P}=$ pastures, $\mathrm{H}=$ human houses, $\mathrm{RE}=$ railway embankments.

\subsection{Frequency Distribution among Habitats}

The habitats with highest frequency of captures were poultry farms and crop field borders, but mainly because of M. musculus and A. azarae captures, respectively (Figure 1). All rodent species were found in at least six of the nine types of habitats sampled, but in some of them with low frequency (Figure 1).

A. azarae was the only species present in all habitats, and in six of them it was present in more than 0.25 of the sites sampled. Its frequency, however, varied by habitat ( $p<0.000$ for the effect of habitat in the GLM analysis), being more frequent in borders of crop fields and pastures and in riparian habitats than in the other habitats (Figure 1).

O. rufus was present in seven habitats, and, as A. azarae, it was more frequently captured in borders of crop fields and pastures and in riparian habitats ( $\mathrm{p}=0.0270$ for the effect of habitat in the GLM analysis). O. rufus, however, was less frequently captured than $A$. azarae (in all habitats it was captured in less than 0.25 of the sites; Figure 1).

The habitat also had an effect on the presence of $O$. flavescens $(\mathrm{p}=0.0124$ for the effect of habitat in the GLM analysis), which showed higher frequencies in pasture borders, railway embankments and woodlots. This species was present in six of the habitats studied (with very low frequency in crop field borders, riparian habitats and poultry farms; Figure 1). 
The habitat also had an effect on M. musculus ( $\mathrm{p}<0.000$ for the effect of habitat in the GLM analysis), which was present in more than $90 \%$ of the poultry farms (Figure 1) but was also captured with low frequency in other five habitats.

C. musculinus and C. laucha were captured in six and seven habitats, respectively, but with frequencies lower than $20 \%$ of the sites, and without significant differences in their frequency among habitats $(p=0.486, p=0.506$ respectively; Figure 1).

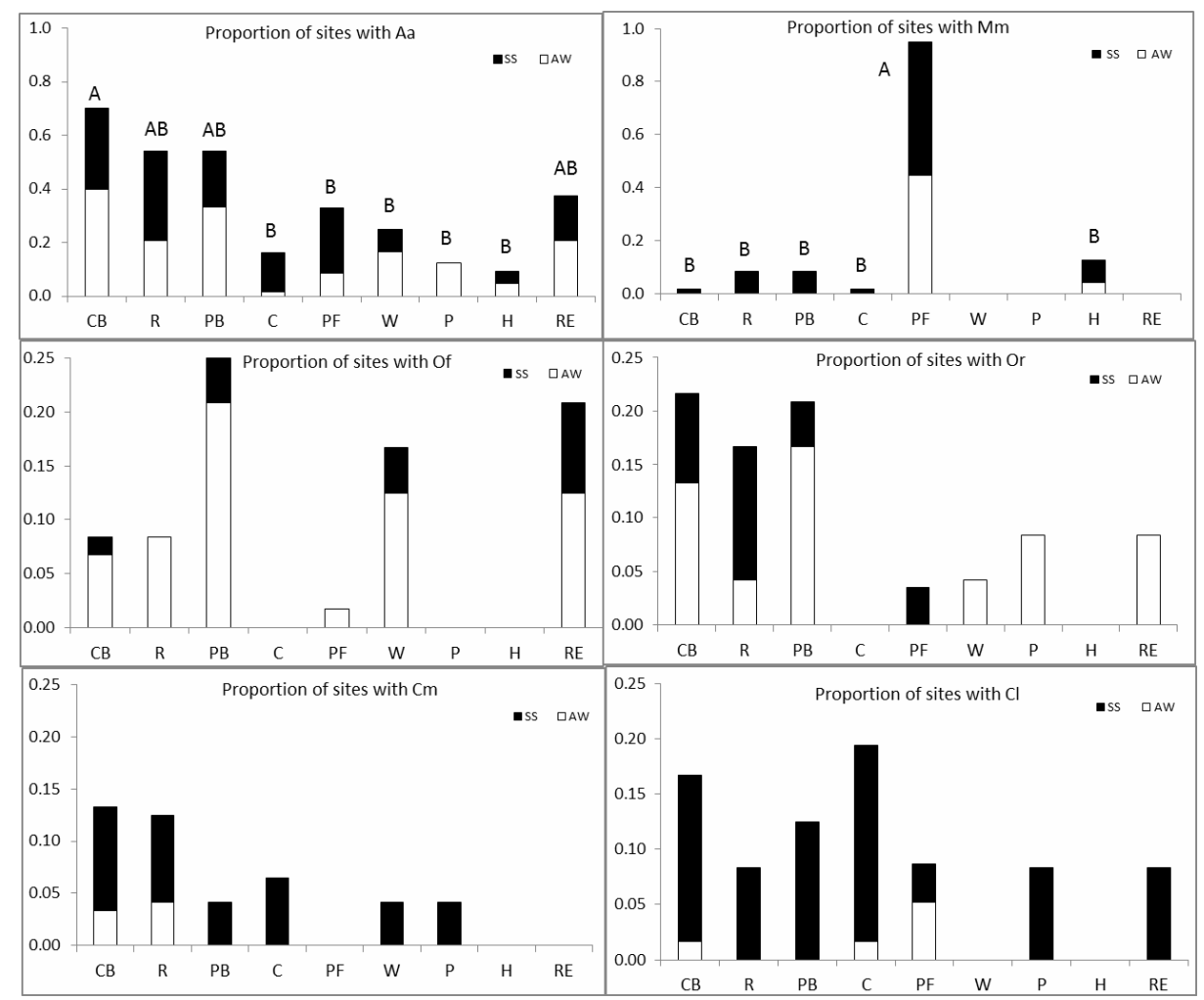

Figure 1. Proportion of sites of each habitat with at least one rodent captured for each species

Note. $\mathrm{Aa}=A$. azarae $; \mathrm{Mm}=M$. musculus, $\mathrm{Of}=O$. flavescens, $\mathrm{Or}=O$. rufus, $\mathrm{Cm}=C$. musculinus, $\mathrm{Cl}=C$. laucha, $\mathrm{SS}=$ spring-summer period, $\mathrm{AW}=$ autumn-winter period, $\mathrm{CB}=$ crop field borders, $\mathrm{R}=$ riparian habitat, $\mathrm{PB}=$ pasture borders, $\mathrm{C}=$ crop fields, $\mathrm{PF}=$ poultry farms, $\mathrm{W}=$ woodlots, $\mathrm{P}=$ pastures, $\mathrm{H}$ : human houses, $\mathrm{RE}=$ railway embankments. Different letters represent significant differences according to the LSD comparisons.

\subsection{Abundance Distribution among Habitats}

Abundance was higher in borders than in the other habitats, while human houses were characterized by a low total abundance and the capture of only one species: M. musculus or A. azarae, depending on the occasion.

The different habitats sampled differed in their contribution to the abundance of each species. Crop field and pasture borders contributed more than $40 \%$ to the abundance of A. azarae, O. rufus, O. flavescens and $C$. musculinus. These habitats also contributed a high proportion of $C$. laucha abundance, while M. musculus individuals were highly concentrated in poultry farms. Woodlots and railway embankments also showed a high contribution to $O$. flavescens abundance (Figure 2).

According to the GLM, the habitat had a significant effect on the abundance of the different species except for $C$. musculinus ( $\mathrm{p}<0.000$ for A. azarae, $\mathrm{p}<0.000$ for M. musculus, $\mathrm{p}=0.003$ for $O$. flavescens, $\mathrm{p}<0.000$ for $O$. rufus and $\mathrm{p}=0.001$ for $C$. laucha).

A. azarae was the species with highest mean abundance, although more than $46 \%$ of its abundance was concentrated in borders of crop fields and pastures. Riparian habitats and railway embankments also had high abundance (Figure 2). LSD comparisons showed that in crop fields, woodlots, human houses and poultry farms its abundance was lower than in riparian habitats, pastures and borders of crop fields and pastures (Figure 2). $M$. 
musculus had the second highest mean abundance, but it was mainly present in poultry farms (Figure 2). $O$. flavescens was more abundant in pasture borders, but woodlots, railway embankments and crop field borders also had higher abundance than the other habitats. LSD comparisons showed that in those habitats its abundance was higher than in poultry farms (Figure 2). O. rufus was the fourth species in abundance, being more abundant in borders of pastures and crop fields than in the other habitats, although differences were only statistically significant when compared with poultry farms. C. laucha abundance was mainly concentrated in crop fields and borders of pastures. LSD comparisons showed that its abundance was higher in crop fields than in poultry farms (Figure 2). C. musculinus was more abundant in crop field borders and riparian habitats, but according to the GLM there was no significant effect of habitat on its abundance.

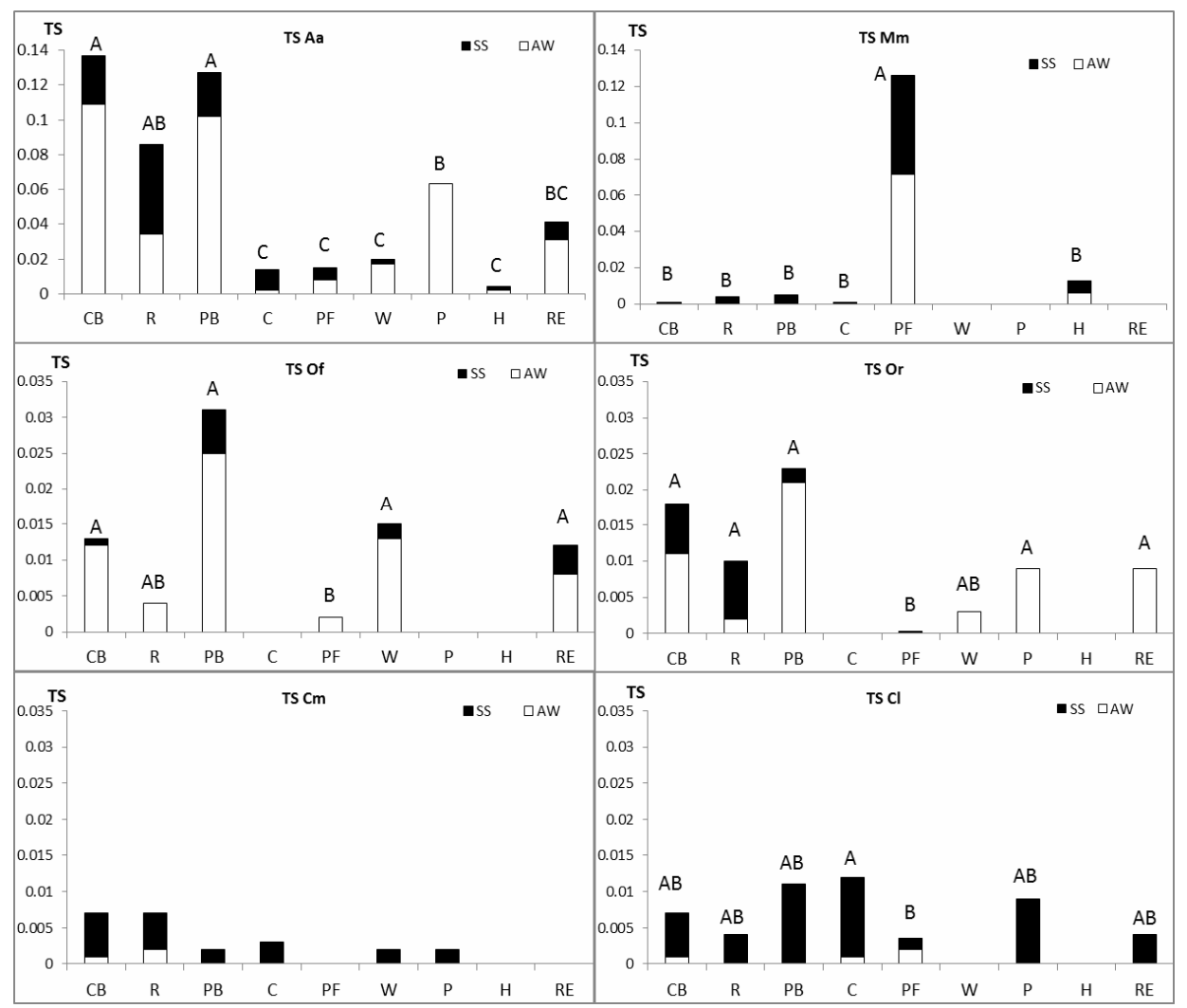

Figure 2. Trapping Success for the different species captured in each habitat

Note. $\mathrm{TS}=$ trapping success, $\mathrm{Aa}=A$. azarae $; \mathrm{Mm}=M$. musculus, $\mathrm{Of}=O$. flavescens $; \mathrm{Or}=O . r u f u s, \mathrm{Cm}=C$. musculinus, $\mathrm{Cl}=$ C. laucha; $\mathrm{SS}=$ spring-summer period, $\mathrm{AW}=$ autumn-winter period, $\mathrm{CB}=$ crop field border, $\mathrm{R}$ = riparian habitats, $\mathrm{PB}=$ pasture borders, $\mathrm{C}=$ crop fields, $\mathrm{PF}=$ poultry farms, $\mathrm{W}=$ woodlots, $\mathrm{P}=$ pastures, $\mathrm{H}=$ human houses, $\mathrm{RE}=$ railway embankments. Different letters represent significant differences according to the LSD comparisons.

\subsection{Species Composition of the Study Area at a Landscape Scale and Changes According to Four Different Scenarios of Land Use Change}

Crop fields occupied more than $88 \%$ of the area, while the other types of habitats occupied between 3 and $0.07 \%$ (Table 3). In scenarios 1 and 2, we considered an increase in the proportion of area covered by crop fields and human habitats (Table 3 ). 
Table 3. Proportion of area occupied by different habitats of the study area and the four possible scenarios of change proposed

\begin{tabular}{llllll}
\hline Habitat & Current Area & Scenario 1 & Scenario 2 & Scenario 3 & Scenario 4 \\
\hline R & 0.0231 & 0.0231 & 0.0231 & 0.0231 & 0.0231 \\
CB & 0.0235 & 0.0117 & 0.0077 & 0.0077 & 0.0077 \\
PB & 0.0007 & 0.0003 & 0 & 0 & 0 \\
C & 0.8837 & 0.9053 & 0.9176 & 0.6882 & 0.4588 \\
PF & 0.0033 & 0.01 & 0.014 & 0.014 & 0.014 \\
W & 0.0108 & 0.0075 & 0.003 & 0.003 & 0.003 \\
P & 0.0273 & 0.01 & 0 & 0 & 0 \\
H & 0.0054 & 0.01 & 0.0125 & 0.0125 & 0.0125 \\
RE & 0.0113 & 0.0113 & 0.0113 & 0.0113 & 0.0113 \\
Rd & 0.0109 & 0.0108 & 0.0108 & 0.0108 & 0.0108 \\
\hline
\end{tabular}

Note. $\mathrm{R}=$ riparian habitat, $\mathrm{CB}=$ crop field border, $\mathrm{PB}=$ pasture border, $\mathrm{C}=$ crop fields, $\mathrm{PF}=$ Poultry farms, $\mathrm{W}=$ woodlots, $\mathrm{P}=$ pastures, $\mathrm{H}=$ human houses, $\mathrm{RE}=$ railway embankments, $\mathrm{Rd}=$ roads.

Habitat diversity and evenness were $\mathrm{H}=0.253$ and $\mathrm{E}=0.253$ ( $\mathrm{n}=9$ habitats) for the current distribution of areas, $\mathrm{H}=0.220$ and $\mathrm{E}=0.220(\mathrm{n}=9)$ for scenario 1 , and $\mathrm{H}=0.189$ and $\mathrm{E}=0.2019(\mathrm{n}=7)$ for scenario 2. In this last case, we assumed the loss of pastures and their borders.

Rodent diversity and evenness were $\mathrm{H}=0.550$ and $\mathrm{E}=0.707$ for the current situation, $\mathrm{H}=0.583$ and $\mathrm{E}=0.749$ for scenario 1 and $\mathrm{H}=0.580$ and $\mathrm{E}=0.745$ for scenario 2 . In all cases, the number of species was 6 . In scenario 1 , rodent diversity increased because of the decrease in the dominance of $A$. azarae, while the loss of habitats in scenario 2 caused a decrease in rodent diversity with respect to scenario 1.

Habitats that have a high local abundance of rodents but cover a low proportion of the area, as poultry farms, pasture and crop field borders, decreased their contribution to rodent abundance at a landscape scale, whereas crop fields increased their contribution to rodent abundance at a landscape scale (Table 4).

Table 4. Percentage contribution of each habitat to the abundance of each species at local and landscape scale

\begin{tabular}{|c|c|c|c|c|c|c|c|}
\hline Habitat & & A. azarae & O. flavescens & O. rufus & C. musculinus & C. laucha & M. musculus \\
\hline $\mathbf{R}$ & LS & 9.96 & 12.03 & 21.76 & 5.84 & 0.80 & 7.22 \\
\hline \multirow[t]{2}{*}{ CB } & $\mathrm{L}$ & 27.08 & 16.98 & 24.79 & 32.11 & 14.52 & 0.38 \\
\hline & LS & 16.12 & 42.82 & 39.86 & 6.12 & 1.57 & 1.22 \\
\hline PB & LS & 0.45 & 3.12 & 1.48 & 0.05 & 0.07 & 0.30 \\
\hline \multirow[t]{2}{*}{ C } & $\mathrm{L}$ & 2.73 & 0 & 0 & 11.93 & 23.24 & 0.38 \\
\hline & LS & 61.16 & 0 & 0 & 85.44 & 94.68 & 46.04 \\
\hline $\mathbf{P F}$ & $\mathrm{L}$ & 2.89 & 1.62 & 0.83 & 0 & 5.81 & 85.55 \\
\hline \multirow[t]{2}{*}{$\mathbf{P}$} & $\mathrm{L}$ & 12.39 & 0 & 12.67 & 8.26 & 19.09 & 0 \\
\hline & LS & 8.57 & 0 & 23.66 & 1.83 & 2.40 & 0 \\
\hline \multirow[t]{2}{*}{ H } & $\mathrm{L}$ & 0.71 & 0 & 0 & 0 & 0 & 8.29 \\
\hline & LS & 0.10 & 0 & 0 & 0 & 0 & 6.19 \\
\hline \multirow[t]{2}{*}{$\mathbf{R E}$} & $\mathrm{L}$ & 8.08 & 15.90 & 12.67 & 0 & 7.47 & 0 \\
\hline & LS & 2.31 & 19.28 & 9.80 & 0 & 0.39 & 0 \\
\hline
\end{tabular}

Note. $\mathrm{R}=$ riparian habitat, $\mathrm{CB}=$ crop field border, $\mathrm{PB}=$ pasture border, $\mathrm{C}=$ crop fields, $\mathrm{PF}=$ Poultry farms, $\mathrm{W}=$ 
woodlots, $\mathrm{P}=$ pastures, $\mathrm{H}=$ human houses, $\mathrm{RE}=$ railway embankments, $\mathrm{L}=$ local scale, $\mathrm{LS}=$ landscape scale.

According to the current area occupied by the different habitats, there is a clear dominance of $A$. azarae (Figure 3a). An increase in the area covered by crop fields and human habitats (poultry farms and human houses) led to an increase in the abundance of $M$. musculus, C. laucha and C. musculinus and to a decrease in the relative abundance of other species (Figures $3 \mathrm{a}, 3 \mathrm{~b}$ and $3 \mathrm{c}$ ).

Considering that the use of crop fields by rodents is restricted to a strip boundary near the borders (Busch \& Hodara, 2010), we found an increase in the proportion of the exotic M. musculus and a decrease in the proportions of C. laucha and C. musculinus (Figures $3 \mathrm{~d}$ and $3 \mathrm{e}$ ).

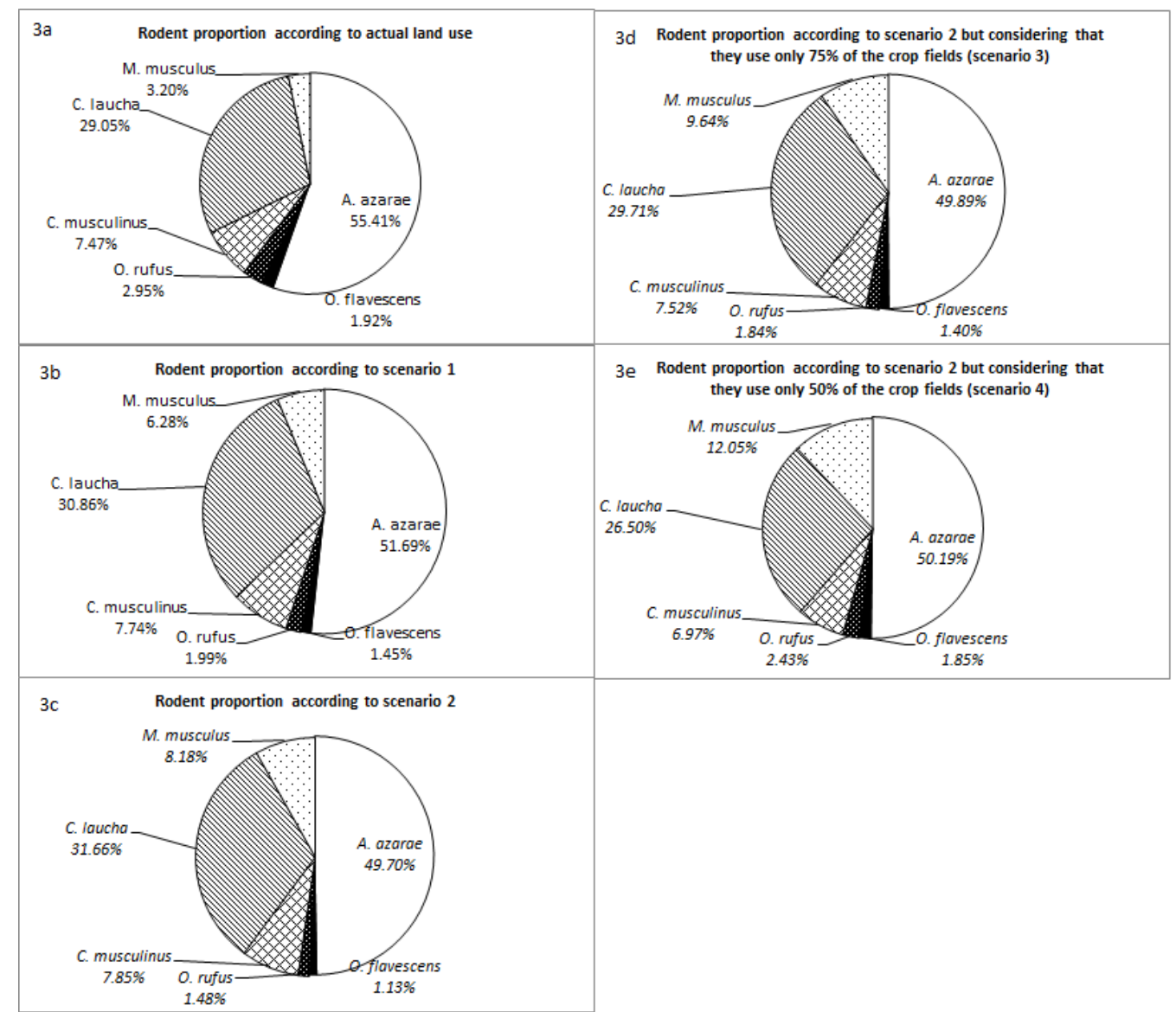

Figure 3. Proportion of the different rodent species according to the current distribution of habitats and under two scenarios of land use change $(a, b, c)$. Rodent proportions considering that the use of crop fields is restricted to a strip boundary near the borders because of an increase in the plot size (d, e, scenarios 3 and 4 )

\section{Discussion}

This study remarks the importance of taking into account the spatial aspect of the distribution of habitats, because the proportion of species in the community at the landscape scale differs with respect to the local composition of the different habitats. None of the species was restricted to a singular habitat, and, except human houses, none of the habitats studied had only one or few species. However, species composition differed among habitats. Habitat similarities were related to habitat use: anthropic habitats had higher similarity indexes between them than with the more natural habitats. Crop fields, along with houses and poultry farms, are the habitats more subject to human intervention, with a periodicity that depends on the crops implanted. The expansion of agriculture has caused an increase in abundance at a landscape scale of both species of Calomys with respect to $A$. azarae, because the population cycle of Calomys is highly synchronized with the phenology of maize, and the rotation of summer and winter crops favors the increase in these rodent populations (Kravetz \& De Villafañe, 1981). During the last decades, however, the increase in soybean culture has caused a reversal of this trend (Fraschina et al., 2012). 
With the changes proposed in scenarios 1 and 2, we observed that $A$. azarae. $O$. rufus and $O$. flavescens would be the species most affected because they are associated with borders and less perturbed habitats. On the other hand, C. laucha, C. musculinus and M. musculus increased their representation due to the increase in crop fields in the case of the two former species and due to the increase in poultry farms in the case of the latter. If we consider scenarios 3 and 4 and take into account that rodent species do not use all the area of crop fields equally (during agricultural labors they move to borders that are less affected, and then the use of fields is limited by the range of movements, which is usually less than $50 \mathrm{~m}$ ), the proportion of species associated with less perturbed habitats in the community decreases. The increase in size of agricultural plots is an increasing trend in the area, and in many cases internal fences are removed, along with the weed community. Previous results have shown a negative relation between the abundance of C. musculinus and C. laucha and field size (Adduci, Bustos, Gorosito, Fraschina, \& Busch, 2012), and the effect of increased plot size has been proposed as an explanation of the decrease in C. laucha abundance between 1984 and 2008, along with the increase in soybean and no tillage methods (Fraschina, 2011).

The persistence of $M$. musculus in this system depends on the presence of commensal habitats, as poultry farms and houses. An evidence of the dependence of M. musculus on human dwellings was its disappearance from a farm when it was abandoned. This farm was invaded by weeds and colonized by native rodent species which were rare before (León, Fraschina, \& Busch, 2010). However, its presence in other habitats, in some cases far from poultry farms or houses, suggests that an increase in the proportion of the area used for poultry and a decrease in the distance among farms may favor its expansion and population increase (León et al., 2010). In Pampean crop fields, this species rarely achieves pest densities, probably because of the competition with native species (Busch et al., 2005). In poultry farms, however, it reaches high densities and causes many economic losses (Acha \& Szyfres, 1992). If along with an increase in the area covered by its favorable habitat and a decrease in the distances that this species needs to travel among different farms, there is a decrease in abundance of native species because of habitat changes, it is likely that M. musculus also becomes a pest species in crop fields, as in Australia and New Zealand, where it is considered one of the most important pests of agriculture (Jacob, Nolte, Hartono, Subagja, \& Sudarmaji, 2003; Pocock, Hauffe, \& Searle, 2005).

\section{Conclusion}

Considering the role of habitat diversity in rodent diversity, our results suggest that none of the species studied, except M. musculus, which is highly dependent on farms, depends on a single habitat and that their abundance is supported by a variety of less perturbed habitats. Both the distribution of habitats and rodent abundance in the agroecosystem studied are characterized by low evenness, because of the dominance of one habitat type, the crop field, and the presence of one or two species, namely A. azarae and M. musculus. The loss of habitats with low human intervention, as borders of pastures and crop fields, pastures and woodlots, would cause a decrease in the abundances of $A$. azarae, $O$. flavescens and $O$. rufus. Probably the least affected of these species is $A$. azarae, because it is more widely distributed (present in more than $25 \%$ of sites of six of the habitats studied) and more abundant.

The current changes in land use would generate an increase in M. musculus abundance in detriment of wildlife species which are associated with undisturbed habitats.

\section{Acknowledgements}

We thank Diego Gaynor people for their assistance during field work. We also thank M. S. Fernandez for her statistical advice. This work was funded by Agencia Nacional de Promoción Científica y Tecnológica (PICT 33513), CONICET PIP 112-200801-01410 and University of Buenos Aires (UBACyT X621 and X47) grants.

\section{References}

Aars, J., \& Ims, R. A. (1999). The effect of habitat corridors on rates of transfer and interbreeding between vole demes. Ecology, 80, 1648-1655. http://dx.doi.org/10.2307/176553

Acha, P. N., \& Szyfres, B. (1992). Zoonosis y enfermedades transmisibles comunes al hombre y a los animales. OPS (2nd ed.). Washington D.C.

Adduci, L., Bustos, N., Gorosito, I. L., Fraschina, J., \& Busch, M. (2012). Efectos del tipo de cultivo, contexto y tamaño de las parcelas sobre la abundancia de pequeños roedores en bordes y campos de cultivo de maíz y soja. Reunión Argentina de Ecología; Lujan, Bs. As.

Angelstam, P., \& Pettersson, B. (1997). Principles of present Swedish forest biodiversity management. Ecological Bulletins, 46, 191-203. Retrieved from http://www.jstor.org/stable/20113216 
Bilenca, D. N., \& Kravetz, F. O. (1995). Patrones de abundancia relativa en ensambles de pequeños roedores de la región pampeana. Ecología Austral, 5, 21-30. Retrieved from http://www.ecologiaaustral.com.ar/index2.php

Bilenca, D. N., \& Kravetz, F. O. (1998). Seasonal variations in microhabitat use and food habits of the Pampas mouse, Akodon azarae, in agroecosystems of central Argentina. Acta Theriologica (Bialowieza, Polonia), 43, 195-203. Retrieved from http://rcin.org.pl/Content/12764/BI002_2613_Cz-40-2_Acta-T43-nr16-195-203_o.pdf

Bolger, D. T., Alberts, A. C., Sauvajot, R. M., Potenza, P., McCalvin, C., Tran, D., Mazzoni, S., \& Soulé, M. E. (1997). Response of rodents to habitat fragmentation in coastal southern California. Ecological Applications 7, 552-563. http://dx.doi.org/10.1890/1051-0761(1997)007[0552:RORTHF]2.0.CO;2

Bowers, M. A., \& Dooley, J. L. Jr. (1991). Landscape composition and the intensity and outcome of two- species competition. Oikos, 60, 180-186. Retrieved from http://www.jstor.org/stable/3544864

Busch, M., \& Kravetz, F. O. (1992a). Competitive interactions among rodents (Akodon azarae, Calomys laucha, C. musculinus and Oligoryzomys flavescens) in a two-habitat system. I. Spatial and numerical relationships. Mammalia, 56, 45-56. http://dx.doi.org/10.1515/mamm.1992.56.1.45

Busch, M., \& kravetz, F. O. (1992b). Competitive interactions among rodents (Akodon azarae, Calomys laucha, C. musculinus and Oligoryzomys flavescens) in a two-habitat system. II. Effect of species removal. Mammalia, 56, 541-554. http://dx.doi.org/10.1515/mamm.1992.56.4.541

Busch, M., Alvarez, M. R., Cittadino, E. A., \& Kravetz, F. O. (1997). Habitat selection and interspecific competition in rodents in pampean agroecosystems. Mammalia, 61, 167-184. http://dx.doi.org/10.1515/mamm.1997.61.2.167

Busch, M., Miño M., Dadon, J. R., \& Hodara, K. (2000). Habitat selection by Calomys musculinus (Muridae, Sigmodontinae) in crop areas of the pampean region, Argentina. Ecología Austral, 10, 15-26. Retrieved from http://www.ecologiaaustral.com.ar/index2.php

Busch, M., Miño, M. H., Dadon, J. R., \& Hodara, K. (2001). Habitat selection by Akodon azarae and Calomys laucha (Rodentia, Muridae) in Pampean agroecosystems. Mammalia, 65, 29-48. http://dx.doi.org/10.1515/mamm.2001.65.1.29

Busch, M., Bilenca, D. N., Cittadino, E. A., \& Cueto, G. R. (2005). Effect of removing a dominant competitor, Akodon azarae (Rodentia, Sigmodontinae) on community and population parameters of small rodent $\begin{array}{llll}\text { species in Central Argentina. Austral Ecology, 30(1), 168-178. } & \text {. }\end{array}$ http://dx.doi.org/10.1111/j.1442-9993.2004.01434.x

Busch, M., \& Hodara, K. (2010). Uso y selección de habitat y competencia interespecífica en roedores sigmodontinos de la región pampeana. In J. J. Polop \& M. Busch (Eds.), Biología y Ecología de pequeños roedores en la región Pampeana de Argentina. Enfoques y perspectivas. Editorial Universidad Nacional de Córdoba, Argentina.

Cole, E. C., Mc Comb, W. C., Newton, M., Leeming, J. P., \& Chambers, C. L. (1998). Response of small mammals to clear cutting, burning and glyphosate application in the Oregon Coast range. Journal of Wildlife Management, 62, 1207-1216. Retrieved from http://www.jstor.org/stable/3801984

Crespo, J. A. (1966). Ecología de una comunidad de roedores silvestres en el Partido de Rojas, Provincia de Buenos Aires. Revista del Museo Argentino de Ciencias Naturales Bernardino Rivadavia, 1, 79-134.

Di Rienzo, J. A., Casanoves, F., Balzarini, M. G., Gonzalez, L., Tablada, M., \& Robledo, C. W. (2014). InfoStat version 2014. Grupo InfoStat, FCA, Universidad Nacional de Córdoba, Argentina. Retrieved from http://www.infostat.com.ar

Donald, P. F. (2004). Biodiversity Impacts of Some Agricultural Commodity Production Systems. Conservation Biology, 18(1), 17-38. http://dx.doi.org/10.1111/j.1523-1739.2004.01803.x

Ellis, B. A., Mills, J. N., Childs, J. E., Muzzini, M. P., McKee, Jr. K. T., Enría, D. A., \& Glass, G. E. (1997). Structure and floristics of habitat associated with five rodent species in an agroecosystem in Central Argentina. Journal of Zoology, 243, 437-460. http://dx.doi.org/10.1111/j.1469-7998.1997.tb02794.x

Forman, R. T. T., \& Gordon, M. (1986). Landscape Ecology. John Wiley \& Sons, New York.

Fraschina, J. (2011). Efectos de cambios en el uso de la tierra sobre ensambles de roedores en agroecosistemas Pampeanos. Tesis Doctoral, Facultad de Ciencias Exactas y Naturales, Universidad de Buenos Aires. 
Retrieved from http://digital.bl.fcen.uba.ar/Download/Tesis/Tesis_4937_Fraschina.pdf

Fraschina, J., León, V., \& Busch, M. (2012). Long term variations in rodent abundance in a rural landscape of the Pampa, Argentina. Ecological Research, 27, 191-202. http://dx.doi.org/10.1007/s11284-011-0888-2

Ghersa, C. M., Ferraro, D. O., Omacini, M., Martinez-Ghersa, M. A., \& Perelman, S. (2002). Farm and landscape level variables as indicators of sustainable land-use in the Argentine Inland-Pampa. Agriculture, Ecosystems \& Environment, 93, 279-293. http://dx.doi.org/10.1016/S0167-8809(01)00351-6

Gómez Villafañe, I. E., \& Busch, M. (2007). Spatial and temporal patterns of brown rat (Rattus norvegicus) abundance variation in poultry farms. Mammalian Biology, 72, 364-371. http://dx.doi.org/10.1016/j.mambio.2006.09.002

Guershman, J. P., Paruelo, J. M., \& Burke, I. C. (2003). Land Use Impacts on the Normalized Difference Vegetation Index in Temperate Argentina. Ecological Application, 13, 616-628. http://dx.doi.org/10.1890/1051-0761(2003)013[0616:LUIOTN]2.0.CO;2

Grant, W. E., Birney, E. C., French, N. E., \& Swift, D. M. (1982). Structure and productivity of grassland small mammal communities related to grazing- induced changes in vegetative cover. Journal of Mammalogy, 63, 248-260. http://dx.doi.org/10.1046/j.1461-0248.2001.00230.x

Haddad, N. M., Bowne, D. R., Cunningham, A., Danielson, B. J., Levey, D. J., Sargent, S., \& Spira, T. (2003). $\begin{array}{lllll}\text { Corridor use by diverse taxa. Ecology, 84, } & \text { 609-615. }\end{array}$ http://dx.doi.org/10.1890/0012-9658(2003)084[0609:CUBDT]2.0.CO;2

Hall, A. J., Rebella, C. M., Ghersa, C. M., \& Culot, P. H. (1992). Field-crop systems of the Pampas. In C. J. Pearson (Ed.), Field crop ecosystems. Ecosystems of the world (Vol. 18, pp. 413-449). Elsevier, Amsterdam.

Hassall, M., Hawthorne, A., Maudsley, M., White, P., \& Cardwell, C. (1992). Effects of headland management on invertebrate communities in cereal fields. Agricultural Ecosystems \& Environment, 40, 155-178. http://dx.doi.org/10.1016/0167-8809(92)90090-X

Hodara, K., Busch, M., Kittlein, M. J., \& Kravetz, F. O. (2001). Density dependent habitat selection between maize cropfields and their borders in two rodent species (Akodon azarae and Calomys laucha) of Pampean agroecosystems. Evolutionary Ecology, 14, 571-593. http://dx.doi.org/10.1023/A:1010823128530

Hodara, K., \& Busch, M. (2006). Return of preferred habitats (edges) as a function of distance in Akodon azarae (Rodentia, Muridae) in cropfield-edge systems of central Argentina. Journal of Ethology, 21, 141-145. http://dx.doi.org/10.1007/s10164-005-0173-3

Jacob, J., Ylönen, H., Runcie, M. J., Jones, D. A., \& Singleton, G. R. (2003). What affects bait uptake by house mice in Australian grain fields? Journal of Wildlife Management, 67, 341-351. http://dx.doi.org/10.2193/0022-541X(2004)068[1130:TIOSFO]2.0.CO;2

Kotliar, N. B., \& Wiens, J. A (1990). Multiple Scales of Patchiness and Patch Structure: A Hierarchical Framework for the Study of Heterogeneity. Oikos, 59, 253-260. http://dx.doi.org/10.2307/3545542

Kravetz, F. O., \& De Villafañe, G. (1981). Poblaciones de roedores en cultivos de maíz durante las etapas de madurez y rastrojo. Historia Natural, 1, 213-232.

Kravetz, F. O., Percich, R. E., Zuleta, G. A., Calello, M. A., \& Weissenbacher, M. C. (1986). Distribution of Junin virus and its reservoirs. A tool for Argentine hemorrhagic fever risk evaluation in non endemic areas. Interciencia, 11, 185-188.

Krebs, C. J. (1989). Ecological Methodology. Harper \& Row, New York.

León, V., Fraschina J., \& Busch, M. (2010). Population subdivision and movements in Mus musculus in an agrarian landscape. Conequences to its control. Canadian Journal of Zoology, 88, 427-435. http://dx.doi.org/10.1139/Z10-014

León, V. A., Fraschina, J., Guidobono, J. S., \& Busch, M. (2013). Habitat use and demography of Mus musculus in a rural landscape of Argentina. Integrative Zoology, 8, 18-29. http://dx.doi.org/10.1111/j.1749-4877.2012.00290.x

Levin, S. A. (1992). The problem of pattern and scale in ecology. Ecology, 73(6), 1943-1967. http://dx.doi.org/10.2307/1941447

Magurran, A. E. (1988). Ecological diversity and its measurement. Croom Helm, London. http://dx.doi.org/10.1007/978-94-015-7358-0. 
Masters, G. J., Brown, V. K., Clarke, I. P., Whittaker, J. B., \& Hollier, J. A. (1998). Direct and indirect effects of climate change on insect herbivores: Auchenorrhyncha (Homoptera). Ecological Entomology, 23, 45-52. http://dx.doi.org/10.1046/j.1365-2311.1998.00109.x

Matteucci, S. D., \& Colma, A. (1982). Study of Vegetation Methodology. Secretaría General de la Organización de los Estados Americanos, Washington.

McGarical, \& McComb, W. C. (1995). Relationships between landscape structure and breeding birds in the Oregon Coast Range. Ecological Monographs, 65, 235-260. http://dx.doi.org/10.2307/2937059

Michel, N., Burel, F., \& Butet, A. (2006). How does landscape use influence small mammal diversity, abundance and biomass in hedgerow networks of farming landscapes? Acta Oecologica, 30, 1-20. http://dx.doi.org/10.1016/j.actao.2005.12.006

Millan de la Pena, N., Butet, A., Delettre, Y., Paillat, G., Morant, P., Le Du, L., \& Burel, F. (2003). Response of small mammals community to changes in western French agricultural landscapes. Landscape Ecology, 18, 265-278. http://dx.doi.org/10.1023/A:1024452930326

Mills, J. N., Ellis, B. A., McKee, K. T., Maiztegui, J. I., \& Childs, J. E. (1991). Habitat associations and relative densities of rodent populations in cultivated areas of Central Argentina. Journal of Mammalogy, 72, 470-479. Retrieved from http://digitalcommons.unl.edu/zoonoticspub/82

Miño, M. H., Cavia, R., Gómez Villafañe, I. E., Bilenca, D. N., \& Busch, M. (2007). Seasonal abundance and distribution among habitats of small rodents on poultry farms. International journal of pest management, 53 , 311-316. http://dx.doi.org/10.1080/09670870601105949

Pielou, E. C. (1984). The Interpretation of Ecological Data: A Primer on Classification and Ordination. John Wiley Sons, New York.

Pocock, M., Hauffe, H., \& Searle, J. (2005). Dispersal in house mice. Biological Journal of the Linnean Society, 84, 565-583. http://dx.doi.org/10.1111/j.1095-8312.2005.00455.x

Poggio, S. L., Chaneton, E. J., \& Ghersa, C. M. (2010). Landscape complexity differentially affects alpha, beta, and gamma divesities of plants occurring in fencerows and crop fields. Biological Conservation, 143(11), 2477-2486. http://dx.doi.org/10.1016/j.biocon.2010.06.014

Ramankutty, N., Foley, J. A., Norman, J., \& McSweeney, K. (2002). The global distribution of cultivable lands: current patterns and sensitivity to possible climate change. Global Ecology and Biogeography, 11(5), 377-392. http://dx.doi.org/10.1046/j.1466-822x.2002.00294.x

Ricklefs, R. E. (1987). Community Diversity: Relative Roles of Local and Regional Processes. Science, 235(4785), 167-171. http://dx.doi.org/10.1126/science.235.4785.167.PMID 17778629

Robinson, G. R., Holt, R. D., Gaines, M. S., Hamburg, S. P., Fitch, H. S., \& Martinko, E. A. (1992). Diverse and contrasting effects of habitat fragmentation. Science, 257, 524-526. http://dx.doi.org/10.1126/science.257.5069.524

Salek, M., Kreisinger, J., Sedlacek, F., \& Albrecht, T. (2009). Corridor vs. hayfield matrix use by mammalian predators in an agricultural Landscape. Agriculture, Ecosystems \& Environment, 134, 8-13. http://dx.doi.org/10.1016/j.agee.2009.06.018

Schweiger, E. W., Diffendorfer, J. E., Holt, R. D., Pierotti, R., \& Gaines, M. S. (2000). The interaction of habitat fragmentation, plant and small mammal succession in an old field. Ecol. Monogr., 70, 383-400. Retrieved from http://www.inhs.uiuc.edu/ jdiffen/documents/Schweiger_et_al_2000.pdf

Soriano, A., León, R., Sala, O., Lavado, R., Deregibus, V., Cauhepe, M., ... Lemcoff, J. (1991). Río de la Plata Grassland. In Coupland R (Ed.) Ecosystems of the world. Natural grasslands. Introduction and western hemisphere (pp. 367-407). Elsevier, Amsterdam.

Tilman, D., Reich, P. B., Knops, J., Wedin, D., Mielke, T., \& Lehman, C. (2001). Diversity and Productivity in a Long-Term Grassland Experiment. Science, 294, 843-845. http://dx.doi.org/10.1126/science.1060391

Vega, E., Balde, G., Jobbagy, E. G., \& Paruelo, J. (2009). Land use change patterns in the Rio de la Plata grasslands: the influence of phytogeographic and political boundaries. Agriculture, Ecosystems \& Environment, 134, 287-292. http://dx.doi.org/10.1016/j.agee.2009.07.011

Vervoorst, F. (1967). Las comunidades vegetales de la depresión del Salado. Serie Fitogeográfica 7. La vegetación de la República Argentina. Buenos Aires, SEAGN-INTA. 
Viglizzo, E. F., Lertora, F., Pordomingo, A. J., Bernardos, J. N., Roberto, Z. E., \& Del Valle, H. (2001). Ecological lessons and applications from one century of low external-input farming in the Pampas of Argentina. Agriculture, Ecosystems \& $\quad$ Environment, $\quad 83, \quad 65-81$. http://dx.doi.org/10.1016/S0167-8809(00)00155-9

Wiens J. A., Stenseth N. C., Van Horne, B., \& Ims, R. A. (1993). Ecological mechanisms and landscape ecology. Oikos, 66, 369-380. http://dx.doi.org/10.2307/3544931

\section{Copyrights}

Copyright for this article is retained by the author(s), with first publication rights granted to the journal.

This is an open-access article distributed under the terms and conditions of the Creative Commons Attribution license (http://creativecommons.org/licenses/by/3.0/). 